Utah State University

DigitalCommons@USU

$10-7-2013$

\title{
Tree Reduction and Debris From Mastication of Utah Juniper Alter the Soil Climate in Sagebrush Steppe
}

Kert R. Young

Brigham

Bruce A. Roundy

Brigham Young University

Dennis L. Eggett

Brigham Young University

Follow this and additional works at: https://digitalcommons.usu.edu/sagestep_articles

Part of the Life Sciences Commons

\section{Recommended Citation}

Young, K., B. Roundy, and D. Eggett. 2013. Tree reduction and debris from mastication of Utah juniper alter the soil climate in sagebrush steppe. Forest Ecology and Management, 310: 777-785. http://dx.doi.org/ 10.1016/j.foreco.2013.09.024

This Article is brought to you for free and open access by the Publications at DigitalCommons@USU. It has been accepted for inclusion in Articles by an authorized administrator of DigitalCommons@USU. For more information, please contact digitalcommons@usu.edu.

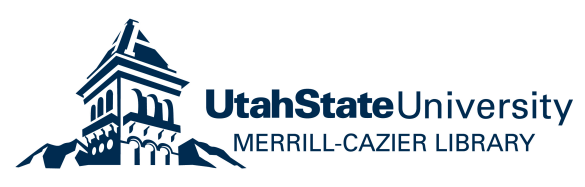


1 Tree reduction and debris from mastication of Utah juniper alter the soil climate in sagebrush steppe

2

4

5

6 Authors are ${ }^{a}$ Postdoctoral Fellow and ${ }^{b}$ Professor, Department of Plant and Wildlife Sciences, Brigham

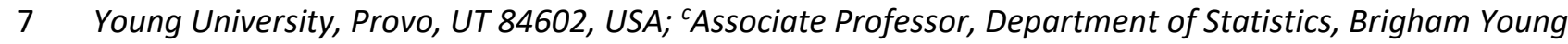

8 University, Provo, UT 84602, USA.

9

10 This is contribution number 98 of the Sagebrush Steppe Treatment Evaluation Project (SageSTEP)

11 funded by the U.S. Joint Fire Science Program, the Bureau of Land Management, and the National

12 Interagency Fire Center.

13

14 Correspondence: Kert Young, Dept of Plant and Wildlife Sciences, 275 WIDB, Brigham Young University,

15 Provo, UT 84602, USA. Phone: (801)422-4133 Email: youngke1@msn.com 
Short Abstract (200 word limit)

17 Juniper (Juniperus spp.) trees are masticated to reduce canopy fuel loads and the potential for crown

18 fire. We determined the effects of tree reduction and soil cover in the forms of tree mounds and

19 masticated debris on hourly soil water potential and soil temperature at $1-30 \mathrm{~cm}$ soil depth.

20 Measurements were made in masticated and untreated areas at three sites in the western Utah portion

21 of the Great Basin. Cumulative seasonal-response variables included wet days (>-1.5 MPa), degree days

$22\left(>0{ }^{\circ} \mathrm{C}\right)$, and wet degree days $\left(>-1.5 \mathrm{MPa}\right.$ and $\left.>0{ }^{\circ} \mathrm{C}\right)$. Masticated areas had 27 more wet days $(\mathrm{P}<$

23 0.001), 32 more degree days $(P=0.007)$, and 311 more wet degree days $(P<0.001)$ than untreated

24 areas across soil depths and seasons. Soil cover had less influence on these soil climate variables than

25 tree reduction. Most importantly, tree reduction increased wet days $(P<0.001)$ by an average of 44.5

26 days during the spring and summer growing seasons at depths of $13-30 \mathrm{~cm}$. Managers are advised to

27 masticate trees while desired understory cover remains high in order to minimize water available to

28 weeds. 
Abstract (400 word limit)

Millions of hectares of sagebrush (Artemisia tridentata Nutt.) and bunchgrass plant communities in the semiarid western United States have become dominated by juniper trees (Juniperus spp.). Trees are mechanically masticated to reduce the potential for wildfire associated with increased canopy fuel loads and to increase the dominance of pre-encroachment plant species. Trees could also be harvested for biofuels in the future. We separated the effects of juniper tree mastication on soil climate into tree reduction and soil cover. Tree reduction included the effects of reduced resource uptake and shade by juniper trees, and soil cover included the effects of tree mounds and masticated-juniper tree debris on the soil climate. In paired masticated and untreated areas of three high-density juniper woodlands in the western Utah portion of the Great Basin, we recorded hourly soil water potential and soil temperature at 1-30 cm soil depth. This range of soil depth comprises the main resource pool for critical spring growth in these systems. Cumulative seasonal-response variables included wet days (summation of

41 hours $24^{-1}$ when hourly soil matric potential > -1.5 MPa), degree days (summation of hours $24^{-1}$ when 42 hourly soil temperature $>0{ }^{\circ} \mathrm{C}$ ), and wet degree days (summation of hours $24^{-1}$ when hourly soil matric 43 potential $>-1.5 \mathrm{MPa}$ and hourly soil temperatures $\left.>0{ }^{\circ} \mathrm{C}\right)$. Masticated areas had 27 more wet days $(\mathrm{P}<$ $440.001), 32$ more degree days $(P=0.007)$, and 311 more wet degree days $(P<0.001)$ than untreated areas across soil depths and seasons. Soil cover had less influence on these soil climate variables than

46 tree reduction, but soil cover did increase wet degree days by 340-394 during spring after mastication 47 reduced juniper resource uptake and shade $(P<0.001)$. Most importantly, tree reduction increased wet days $(P<0.001)$ by an average of 44.5 days during the spring plus summer growing seasons at depths of

$49 \quad 13-30 \mathrm{~cm}$. This major increase in resource availability could support desirable or weedy species.

50 Managers are advised to masticate trees while desired understory cover remains high in order to 51 minimize water available to weeds. 


\section{Key Words}

53 mulch, resistance to invasion, resource availability, soil temperature, soil water, weeds 


\section{Introduction}

Desertification with increased woody plants, reduced perennial grasses, and increased heterogenization of soil resources is one of the most significant changes on rangelands globally in the last 150 years (Schlesinger et al., 1990; Archer et al., 2011). The shift from herbaceous to woody plants in these dryland systems often alters habitat and ecosystem trophic structure (Archer et al., 2011), reduces primary production (Knapp et al., 2008), and increases erosion (Wainwright et al., 2000; Gillette and Pitchford, 2004; Breshears et al., 2009). In the semiarid western United States, juniper trees (Juniperus spp.) have encroached on millions of hectares of sagebrush (Artemisia tridentata Nutt.) steppe and commonly reduced understory plant cover (Johnsen, 1962; West, 1984; Miller and Wigand, 1994; Miller and Rose, 1999; Miller et al., 2000, 2005). Juniper trees reduce the pre-encroachment plant community through competition for and redistribution of resources (Breshears et al., 1997a; Roundy et al., 2013b; Ryel et al., 2010). For example, juniper trees begin transpiration in early spring reducing soil water remaining for understory plants (Angel and Miller, 1994); shallow juniper roots use resources from the same soil depth as grass roots (Emerson, 1932); juniper roots hydraulically move water deeper into the soil profile; and soil water repellant layers below juniper trees funnel water to greater depths away from shallow rooted species and the evaporation zone (Leffler et al., 2002; Robinson et al., 2010). Reduced fire frequency in the sagebrush steppe during the past 100-150 yr has led to dense juniper encroachment (Miller et al., 2000) and increased woody fuel loads. Increased fuel loads following years of fire suppression and property development in fire prone areas led to extensive wildfire damage during the 2000 fire season (PIC, 2002). This prompted the National Fire Plan that appropriated millions of dollars to hazardous fuels reduction across the United States (PIC, 2002). Mechanical reduction of encroaching woodlands is one such fuel reduction method that has been applied on thousands of hectares in the western US. Mechanical mastication of dense juniper woodlands is often used to convert canopy and bole fuels to surface fuels before prescribed fire can 
safely reduce fuel loads without the risk of crown fires escaping and damaging neighboring

79 communities. Juniper tree reduction has also helped pre-encroachment plant communities recover by increasing resources available for residual plants (Miller et al., 2013; Roundy et al., 2013a). Sagebrush steppe communities depend on resources available in resource growth pools when

82 soil water potentials are $>-1.5 \mathrm{MPa}$ within the top $0.3-0.5 \mathrm{~m}$ of soil for major plant growth and diffusion of nutrients to roots in spring and early summer (Leffler and Ryel, 2012; Roundy et al., 2013b; Ryel et al., 2010). The stability of resource pools is especially important to plant community assembly because unusually large increases in resources due to disturbance can lead to increased weedy species dominance (Leffler and Ryel, 2012). Wet and wet degree days are important metrics of resource growth pools because they relate these pools to plant growth by quantifying the amount of time resources are adequate (soil water potential >-1.5 MPa) for rapid growth during each season. The resources remaining after plant growth make up the maintenance pool down to 1-1.5 $\mathrm{m}$ that enables perennial plants like sagebrush to survive summer drought (Leffler and Ryel, 2012). The accurate use of wet,

91 degree, and wet degree day summations to predict specific plant growth responses depends on 92 adequately modeling the linearity or curvilinearity and temperature thresholds of the response 93 (Bonhomme, 2000), as well as accounting for limiting factors besides soil temperature and water availability (Idso et al., 1978; Wang, 1960). In ecosystems where plant response is highly dependent on 95 short periods of soil water availability when soil and air temperatures are warm enough for growth, these metrics indicate soil microenvironmental conditions that support plant establishment and growth. Our major objective was to determine the effects of juniper tree mastication on wet, degree, and wet degree days to indicate favorable growing conditions for plants. The effects of juniper tree 99 mastication can be summarized in two categories. The first category is tree reduction associated with reduced juniper resource uptake and canopy shade. The second category is soil cover associated with 101 preexisting tree mounds and newly added masticated-juniper debris. We sought to determine the 
102 effects of tree reduction separate from soil cover on wet, degree, and wet degree days. With recent

103 work evaluating harvesting of juniper trees for biofuel energy (Jaeger et al., 2007; Skog et al., 2009) and

104 the potential for this to become an important driver of juniper tree reduction, it was also important to

105 evaluate the effects of tree reduction in areas without masticated-juniper debris cover. We

106 hypothesized that: 1) the reduction of juniper resource uptake and shade with juniper tree mastication

107 will increase wet, degree, and wet degree days compared to untreated areas with live juniper trees

108 remaining; 2 ) soil cover will reduce degree days during warm periods, increase degree days during cool

109 periods, and increase wet days and wet degree days throughout the year compared to uncovered soil;

110 and 3) wet days will increase with soil depth throughout the year, degree days will decrease with soil

111 depth during warm periods and increase with soil depth during cool periods, and wet degree days will

112 increase with soil depth during cool periods.

\section{2. Materials and methods}

\section{$114 \quad$ 2.1. Study locations}

We studied the three Sagebrush Steppe Treatment and Evaluation Project (SageSTEP) research

116 locations of Greenville, Onaqui, and Stansbury in the western Utah portion of the Great Basin (Mclver et

117 al., 2010; www.sagestep.org). We measured soil water and temperature in Phase III woodland

118 encroachment (sensu Miller et al., 2005) of sagebrush-bunchgrass communities. Communities are

119 considered to be at Phase III encroachment when tree cover $>67 \%$ of the total relative perennial plant

120 cover. High densities of Utah juniper trees or mixed piñon-juniper trees have depleted the previous

121 sagebrush (Artemisia spp.) and bunchgrass plant communities. Maximum absolute and relative tree

122 cover before mastication were 31 and $89 \%$ at Onaqui, 54 and $97 \%$ at Greenville, and 65 and $93 \%$ at

123 Stansbury. Maximum tree density (>0.5-m tall) prior to mastication was 586 trees ha-1 at Greenville, 444

124 trees ha- ${ }^{-1}$ at Onaqui, and 1,030 trees ha- ${ }^{-1}$ at Stansbury. Before juniper tree mastication, shrub cover was 
$125<5 \%$ across study locations and perennial grass cover was $<10 \%$ at Greenville and Onaqui and $<20 \%$ at 126 Stansbury.

The average elevation at these locations is 1,700-1,900 m. Annual average temperatures at

128 these locations are $9-10{ }^{\circ} \mathrm{C}$ with minimum average temperatures of $0-3^{\circ} \mathrm{C}$ and maximum average

129 temperatures of $16-19{ }^{\circ} \mathrm{C}$. Annual average precipitation ranged between 193 and $389 \mathrm{~mm}$. Most

130 precipitation comes as snow during winter and rain in spring and fall but summers are mostly dry.

131 Greenville $\left(38^{\circ} 12^{\prime} \mathrm{N}, 112^{\circ} 48^{\prime} \mathrm{W}\right)$ in Beaver County is on the north side of the Black Mountains with soils

132 classified as loamy-skeletal, carbonatic, mesic Typic Calcixerepts (Rau et al., 2011). The dominant 133 vegetation includes Utah juniper trees, two-needle piñon trees (Pinus edulis Engelm.), Wyoming big 134 sagebrush (Artemisia tridentata Nutt. ssp. wyomingensis Beetle \& Young), rabbitbrush [Chrysothamnus 135 viscidiflorus (Hook.) Nutt.], bluebunch wheatgrass [Pseudoroegneria spicata (Pursh) A. Löve], needle136 and-thread [Hesperostipa comata (Trin. \& Rupr.) Barkworth], and Indian ricegrass [Achnatherum 137 hymenoides (Roem. \& Schult.) Barkworth]. Onaqui $\left(40^{\circ} 13^{\prime} \mathrm{N}, 112^{\circ} 28^{\prime} \mathrm{W}\right.$ ) in Tooele County is on the east 138 side of the Onaqui Mountains with soils identified as loamy-skeletal, carbonatic, mesic, shallow 139 Petrocalcic Palexerolls (Rau et al., 2011). The dominant vegetation includes Utah juniper trees, Wyoming 140 big sagebrush, bluebunch wheatgrass, Sandberg bluegrass (Poa secunda J. PresI), and Indian ricegrass. 141 Stansbury $\left(40^{\circ} 35^{\prime} \mathrm{N}, 112^{\circ} 39^{\prime} \mathrm{W}\right)$ in Tooele County is on the west side of the Stansbury Mountains with 142 soils identified as loamy-skeletal, mixed, active, frigid Pachic Haploxerolls (Rau et al., 2011). The 143 dominant vegetation includes Utah juniper trees, Wyoming big sagebrush, antelope bitterbrush [Purshia 144 tridentata (Pursh) DC.], bluebunch wheatgrass, Sandberg bluegrass, and cheatgrass (Bromus tectorum 145 L.).

$146 \quad$ 2.2. Treatment Implementation A Tigercat ${ }^{\circledR}$ M726E Mulcher (Tigercat Industries, Inc., Brantford, Ontario) with Fecon ${ }^{\circledR}$ Bull Hog $^{\circledR}$

148 (Fecon, Inc., Lebanon, $\mathrm{OH}$ ) attachment masticated Utah juniper trees at Onaqui in the fall of 2006 and at 
149 Stansbury in the fall of 2007. A skid steer loader with Fecon ${ }^{\circledR}$ Bull Hog ${ }^{\circledR}$ attachment masticated Utah

150 juniper and two-needle piñon trees at Greenville in the fall of 2007. Greenville and Onaqui had 20-ha

151 treatment areas while Stansbury had 5-ha areas. Most of the masticated-juniper debris had diameters <

$152 \quad 2.54 \mathrm{~cm}$ and nearly all of the debris had diameters $<7.62 \mathrm{~cm}$ with lengths varying widely from less than

153 a centimeter to a couple meters. We did not measure residual plant cover or seed banks in this study

154 but removed volunteer plants from microsites where soil climate was measured. Plant growth did not

155 appear to change in untreated areas during our study. Herbaceous plants appeared to increase at

156 Stansbury 1 yr after juniper tree mastication and 2-3 yr after mastication at Greenville and Onaqui.

157 Across the Great Basin, Miller et al. (2013) and Roundy et al. (2013a) found that invasive annual and

158 native perennial herbaceous cover increased 2-3 yr after mechanical reduction of trees at moderate to

159 high levels of juniper-piñon encroachment.

160

161

162 tree litter composed of fallen leaf scales, twigs, and berries; tree mounds with tree litter removed down

172

\subsection{Study Design and Field Measurements}

We paired masticated and untreated control areas with similar soils and pretreatment vegetation at each location to test the effects of reduced juniper tree resource uptake and shade on wet, degree, and wet degree days. We installed a randomized complete block design within each masticated and untreated area. Sixteen juniper trees in masticated areas and eight juniper trees in untreated areas were grouped into four replicate blocks. We selected trees with at least a 2-m diameter tree mound to allow room for soil climate measurements. One tree per block was selected for soil water and temperature measurements in this study.

We sectioned juniper inter- and subcanopy areas into pie shaped microsites to isolate the effects of the different soil cover types and uncovered soil on wet, degree, and wet degree days (Figs. 1 and 2). Juniper trees in untreated areas had three microsite types that included: tree mounds with intact to the soil surface; and bare interspaces between tree canopies with little understory vegetation 
remaining. Juniper trees in masticated areas had five microsite types that included: 1) tree mounds with intact litter; 2) tree mounds with tree litter removed; 3) bare interspaces between tree canopies; 4) bare interspaces covered with masticated-juniper debris mostly composed of wood pieces, bark, and leaf scales; and 5) tree mounds with intact tree litter covered with masticated-juniper debris. The number of microsite experimental units per research location was 32 derived from 4 untreated blocks * 3 microsite types plus 4 masticated blocks * 5 microsite types.

We buried copper-constantan thermocouples (Omega Engineering, Inc., Stamford, CT) to measure soil temperature and gypsum blocks (Delmhorst Instrument Co., Towaco, NJ) to measure soil water potential at Onaqui in October 2007 and at Greenville and Stansbury in July 2008. One of each sensor was buried at 1-3, 13-15, and $28-30 \mathrm{~cm}$ soil depths in each microsite of one randomly selected tree per block. We buried sensors at these depths because the effects of tree reduction and soil cover type on the soil climate were expected to change with soil depth and these depths relate to the resource growth pool (see Section 1; Leffler and Ryel, 2012; Roundy et al., 2013b; Ryel et al., 2010). The difference in rooting depth among species, seasons, solar radiation, evaporation, and hydrophobic layers are also among the several factors that influence the soil climate at different intensities depending on soil depth. Soil water potential and temperature were recorded at Greenville from September 2008 through February 2011; Onaqui from December 2007 through February 2011; and Stansbury from September 2008 through June 2009. We converted electrical resistance as measured by gypsum blocks to soil water potential using a standard calibration curve (Campbell Scientific, Inc., 1983). CR10X data loggers and AM16/32 multiplexers (Campbell Scientific, Inc., Logan, UT) recorded hourlyaverage soil water potential and soil temperature using 1-min interval measurements. Onsite air temperature was recorded hourly using a thermistor in a gill shield. Precipitation was measured using an electronic tipping-bucket rain gauge at each research location to tract annual climate variability throughout the study. 


\subsection{Data Analysis}

Soil water and temperature were analyzed as the seasonal summations of wet days (summation of hours $24^{-1}$ when hourly soil matric potential > $-1.5 \mathrm{MPa}$ ), degree days (summation of hours $24^{-1}$ when hourly soil temperature $>0{ }^{\circ} \mathrm{C}$ ), and wet degree days (summation of hours $24^{-1}$ when hourly soil matric

201 potential >-1.5 MPa and hourly soil temperatures $>0{ }^{\circ} \mathrm{C}$ ) separately using Proc Mixed (SAS v9.2, SAS

202 Institute, Inc., Cary, NC). The four seasons included spring: 1 March to 30 June; summer: 1 July to 31

203 August; fall: 1 September to 30 November; and winter: 1 December to 28 February to account for

204 seasonal weather patterns and plant growth. Analysis of variance data requirements were met without 205 transformation of response variables based on evaluation of residuals plots. Seasons, treatment areas, microsite types, and soil depths were fixed effects, and years, locations, blocks, and trees were random 207 effects in mixed-model analysis of variance. Fixed effects were evaluated with F-tests from maximum 208 likelihood estimation. Microsites as experimental units were nested in trees and trees were nested in 209 years, locations, and blocks. This analysis structure accounted for potential microsite spatial correlation. Season was crossed with years because seasons were the same period of time each year. Season was

211 included as a repeated measures variable to account for potential temporal correlation.

213 microsites than untreated areas, a result of untreated areas not having masticated-juniper debris. We

214 assigned each treatment by microsite type combination to be one of eight levels of the treatment215 microsite main effect. These eight levels were the three untreated and five masticated microsite types.

216 We used linear contrasts to test the overall treatment (tree reduction) effects on soil climate by 217 comparing the three microsite types in untreated areas with the five microsite types in masticated 218 areas. We also used linear contrasts within treatments to test soil cover type effects and across 219 treatments to test tree reduction effects on an individual microsite type basis. We adjusted for false 220 positives from multiple comparisons by using pseudo-Bonferroni with a critical alpha level of 0.001 for 
221 individual microsite and soil depth comparisons. Each response variable had 3,628 observations for

222 analysis.

223 3. Results

\section{3.1. Climate}

225 Climate provides the background upon which the effects of mechanical mastication of juniper

226 influence wet, degree, and wet degree days. Annual-average air temperatures were consistent across

227 years but annual precipitation totals varied greatly across years and were generally lower than long-

228 term averages. Greenville and Onaqui had onsite annual-average air temperatures of $9-10{ }^{\circ} \mathrm{C}$ with

229 minimum temperatures of $0-2{ }^{\circ} \mathrm{C}$ and maximum temperatures of $17-19{ }^{\circ} \mathrm{C}$. Onsite annual air

230 temperature and precipitation data are not available for Stansbury. The long-term annual averages from

231 1970-2007 at Greenville, Onaqui, and Stansbury for minimum air temperature were 0, 2, and $3{ }^{\circ} \mathrm{C}$ and

232 for maximum air temperature were 17,17 , and $16^{\circ} \mathrm{C}$, respectively (PRISM, 2008). Greenville had annual

233 precipitation totals of $193 \mathrm{~mm}$ in 2009 and $387 \mathrm{~mm}$ in 2010. Onaqui had annual precipitation totals of

$234259 \mathrm{~mm}$ in 2008, $287 \mathrm{~mm}$ in 2009, and $370 \mathrm{~mm}$ in 2010. The long-term annual precipitation totals for

235 1970-2007 at Greenville, Onaqui, and Stansbury were 334, 311, and $389 \mathrm{~mm}$, respectively (PRISM,

236 2008).

237 3.2. Tree Reduction - Reduced Juniper Tree Resource Uptake and Shade

238 The treatment-microsite, soil depth, and season main effects and their interactions always

239 influenced wet, degree, and wet degree days $(P<0.001)$ except the treatment-microsite by soil depth

240 interaction did not alter degree days $(P>0.05$, Table 1$)$. Reduced juniper resource uptake and shade

241 with mastication increased wet days, wet degree days, and sometimes degree days compared to

242 untreated areas and these differences increased with soil depth $(P<0.001$, Figs. 3 and 4$)$. The five

243 microsite types in masticated areas collectively had 27 more wet days $(P<0.001), 32$ more degree days

$244(P=0.007)$, and 311 more wet degree days $(P<0.001)$ than the three microsite types in untreated areas 
across soil depths and seasons (Table 2). Importantly, masticated areas during the critical spring-

246 summer growth period averaged 44.5 more wet days than untreated areas across the lower soil depths $247 \quad(P<0.001$, Fig. 3).

Mastication of juniper trees affected tree mound degree days and wet days differently than

249 adjacent interspaces. Reduced juniper canopy shade with mastication increased intact and removed-

250 litter tree mound degree days during spring and summer by 127-309 but increased interspace degree

251 days only during fall by $98-118$ at all soil depths $(P<0.001 ;$ Table 3$)$. Reduced juniper resource uptake

252 increased intact and removed-litter tree mound wet days at most soil depths by 21-63 during fall-spring

253 but increased interspace wet days only at the lowest soil depth by $27-54$ throughout the year $(P<0.001$,

254 Fig. 3). However, the combined effects of reduced juniper resource uptake and shade resulted in both

255 increased tree mound and interspace wet degree days at most soil depths by 282-966 during spring-fall

$256 \quad(\mathrm{P}<0.001$, Fig. 4).

\section{$257 \quad$ 3.3. Soil Cover Types}

Soil cover influenced degree days to greater soil depths than wet days. Soil cover in masticated

259 and untreated areas whether intact litter on tree mounds or masticated-juniper debris on interspaces

260 decreased degree days at most soil depths by 55-265 during spring and summer but increased wet days

261 only at the $1-3 \mathrm{~cm}$ soil depth by $24-31$ during spring $(P<0.001$, Tables 3 and 4$)$. Additionally, soil cover

262 increased masticated wet degree days only at the 1-3 cm soil depth for intact litter on tree mounds by

263 328-394 during spring and summer and for masticated-juniper debris by 340 during spring $(P<0.001$,

264 Table 4). An important thermal difference between soil cover types appeared to be due to color of the

265 soil cover. Dark-colored, intact litter on tree mounds had more degree days by 87-187 than light-

266 colored, masticated-juniper debris during spring and summer at most soil depths $(P<0.001$, Table 3$)$. 


\subsection{Soil Depth}

Most microsite degree days decreased with soil depth during spring and summer by 139-233 but increased with soil depth during fall and winter by $103-174$ regardless of juniper mastication $(P<0.001$, Table 3). Untreated wet days had seasonal trends opposite that of degree days. Untreated, removed-

271 litter tree mound and interspace wet days increased with soil depth during spring by 19-31 and wet 272 degree days also increased with soil depth during spring by 268-418 but wet days decreased with soil 273 depth during fall by 19-24 ( $<<0.001$, Table 4, Figs. 3 and 4). Whereas masticated, intact and removed-

274 litter tree mound and interspace wet days usually increased with depth by 25-40 and wet degree days 275 usually increased with depth by 401-914 during spring-fall $(P<0.001$, Table 4, Figs. 3 and 4).

\section{Discussion}

\subsection{Tree Reduction - Reduced Juniper Tree Resource Uptake and Shade}

Juniper tree encroachment is expected to continue in the sagebrush steppe without treatment.

279 Juniper trees increase dominance by competing with other plants for resources and redistributing soil water and nutrients away from surrounding vegetation to directly below its canopy, which contributes

to desertification (Leffler et al., 2002; Newman et al., 2010; Ryel et al., 2010; Archer et al., 2011).

Because soil water is often the most limiting resource for plant growth in these juniper encroached sagebrush-bunchgrass communities (Young et al., 2013) increased resource availability with juniper tree mastication translates into better growing conditions (Young, 2012). The greater number of wet, degree, and wet degree days and greater soil $\mathrm{N}$ availability (Young, 2012) after juniper tree mastication explain the increased bluebunch and cheatgrass aboveground biomass, tillers, and cheatgrass spikelets found in 287 a related study conducted on the same sites (Young et al., 2013). This indicates that our wet, degree, 288 and wet degree day metrics are good indicators of favorable growing conditions.

The plant species that benefit most from increased resource availability after tree reduction are 
291 morphological and physiological capabilities to quickly take advantage of the increased resource growth

292 pool (Leffler and Ryel, 2012). The use of water from the resource growth pool by one plant can limit the 293 size of the growth pool available to other plants and thereby interfere with their growth (Leffler and

294 Ryel, 2012). This link between plant species performance and resource availability provides land 295 managers with means to modify plant community composition by modifying resource availability with 296 management treatments (Leffler and Ryel, 2012) like mechanical mastication. With the understory plant community often reduced by juniper encroachment (Roundy et al., 298 2013a), the amount of resources made available by juniper reduction increases with the density and cover of juniper trees treated (Roundy et al., 2013b). A concern with treatment at an advanced phase of tree encroachment is that the few remaining desired perennials may not be sufficient to take up the

301 increase in resource availability. This could leave unused resources available for invasive weedy species

302 like cheatgrass to alter the plant community, reduce ecosystem goods and services, and reduce ecosystem resistance to invasion (D'Antonio et al., 2009). For example, following juniper tree mastication, cheatgrass cover increased more at higher phases of juniper tree encroachment than at

305 lower phases (Roundy et al., 2013a). This suggests that juniper tree encroachment should be controlled 306 early before desired perennials are reduced in order to minimize the availability of resources for weedy

307 species and to maximize ecosystem resistance to weeds (D'Antonio et al., 2009). Early control of juniper 308 encroachment will also reduce treatment costs because the $\$ 50-500 \mathrm{ac}^{-1}$ to masticate juniper trees 309 depends on tree density and tree maturity as well as roughness of terrain and remoteness of the 310 treatment site (SageSTEP, 2011).

\section{4.2. Soil Cover Types}

Intact tree mounds and masticated-juniper debris had less of an effect on soil water and

313 temperature than tree reduction but still increased surface wet and wet degree days during spring in 314 masticated areas. Intact tree mounds also increased surface wet degree days during summer in 
masticated areas. The organic, intact tree mounds and masticated-juniper debris conserved soil water

316 by reducing evaporation in multiple ways. Organic cover has low heat capacity and conductivity (Hillel,

317 2004) that allows it to intercept and reduce incident solar energy available to evaporate soil water, as

318 well as maintain cooler soil temperatures during the growing season (Facelli and Pickett, 1991). Organic

319 cover also lowers evaporation by reducing the vapor pressure deficit between the soil and atmosphere

320 (Facelli and Pickett, 1991) and increases infiltration rates (Cline et al., 2010). These longer periods of

321 available water near the soil surface should favor germination (Roundy et al., 2007) and seedling

322 emergence. However, intact tree mounds and masticated-juniper debris did not increase and sometimes

323 decreased bluebunch wheatgrass and cheatgrass emergence (Young et al., 2013) compared to

324 uncovered soil. This suggests that the soil cover physically restricted seedling emergence (Facelli and

325 Pickett, 1991) or that the environmental requirements for seedling establishment were met in covered

326 and uncovered areas.

327 Soil cover also influences plant phenology by altering soil temperatures because warmer

328 temperatures can increase germination and seedling growth rates (Chambers et al., 2007; Rawlins et al.,

329 2012; Roundy et al., 2007). This indicates that the cooler soil temperatures under intact tree mounds

330 and masticated-juniper debris during spring could delay seedling establishment while the lack of soil

331 cover and associated warmer soil temperatures in interspaces could hasten spring seedling emergence.

332 In untreated areas, the minimal effect of soil cover on wet days and wet degree days was associated

333 living trees. Untreated trees still used soil water, shaded subcanopy areas and diurnally shaded some

334 interspaces, and redistributed precipitation and soil water through canopy interception, hydraulic flow

335 through roots, and water repellant layers below litter mounds funneling soil water deeper into the soil

336 away from shallow-rooted plants (Breshears et al., 1997a, 1997b; Lebron et al., 2007; Newman et al.,

337 2010; Young et al., 1984). 


\subsection{Soil Depth}

Degree days frequently decreased with soil depth during spring and summer but increased with

340 soil depth during fall and winter as expected (Table 3). In spring and summer, more direct solar radiation

341 at northern latitudes results in greater warming of surface than subsurface soils (Brady and Weil, 1999).

342 Conversely, in fall and winter, less direct solar radiation results in cooler surface than subsurface soils

343 (Brady and Weil, 1999). These temperature gradients across soil depths can alter invasive-annual

344 seedling establishment relative to native-perennials (Harris, 1967). Rapid root elongation after fall

345 germination of invasive annuals like cheatgrass allows their roots to penetrate deeper into the soil

346 profile where soil temperatures are warmer, thereby supporting winter growth (Harris, 1967). This gives

347 cheatgrass a resource acquisition advantage in early spring over native perennial seedlings like

348 bluebunch wheatgrass whose roots grow slower at cool temperatures (Harris, 1967).

The ratio of herbaceous to woody plant biomass is dependent on the ratio of shallow to deep

350 soil water (Breshears et al., 1997b). The thick juniper stands in untreated areas frequently decreased soil

351 water with soil depth during fall even though soil water often increased with soil depth during spring in

352 untreated areas and throughout the year in masticated areas. This indicates that live juniper trees

353 deplete much of the plant available soil water by the end of summer before the return of fall rains (Fig.

354 3). The reduction in soil water with soil depth likely explains the common reduction of shrub cover with

355 juniper encroachment. These results show that the historic sagebrush steppe community will not return 356 to dominance until juniper encroachment is reduced.

\section{4.4. Conclusions}

Without juniper tree reduction or crown fire, juniper trees are expected to continue dominating

359 sagebrush-bunchgrass communities because they access deeper soil water, compete for and manipulate

360 resources, and decrease understory plant cover (Breshears et al., 2009; Leffler et al., 2002; Miller and

361 Wigand, 1994; Newman et al., 2010; Ryel et al., 2010). The metrics of wet, degree, and wet degree days 
362 are useful tools for evaluating the effects of woody species control on resource availability and

363 subsequent plant performance. Mastication of juniper trees increased the time of plant available soil

364 water when temperatures were warm during spring and summer, a critical time for seedling

365 establishment and plant growth (Hardegree et al., 2003; Roundy et al., 2007). Even when Greenville

366 precipitation in 2009 was only $50 \%$ of 2010 and $58 \%$ of the long-term average, juniper tree mastication

367 increased soil water availability. The increased resource availability is expected to benefit both surviving

368 desirable and weedy plant species adapted to site conditions (Miller et al., 2013). However, to best

369 manage for weed resistance, juniper trees should be controlled well before desirable perennial plant

370 cover is lost to limit resources available to invasive plants. In the future, the metrics of wet, degree, and

371 wet degree days should be evaluated for their potential to monitor the effects of climate change on the

372 soil climate and associated changes in plant community composition. 


\section{Acknowledgements}

We thank the USDI Bureau of Land Management and USDA Forest Service in Utah for helping

375 implement treatments and allowing this research on public lands. We are grateful to the research site

376 managers, April Hulet and Brad Jessop, and the several students that helped with field work. The

377 authors thank the reviewers for constructive comments that helped improve the content of this paper. 


\section{References}

Angell, R.F., Miller, R.F., 1994. Simulation of leaf conductance and transpiration in Juniperus occidentalis. For. Sci. 40, 5-17.

Archer, S.R., Davies, K.W., Fulbright, T.E., McDaniel, K.C., Wilcox, B.P., Predick, K.I., 2011. Brush management as a rangeland conservation strategy: A critical evaluation. In: Briske, D.D., (Ed.). Conservation Benefits of Rangeland Practices: Assessment, Recommendations, and Knowledge Gaps. USDA, NRCS, pp. 105-170.

Bonhomme, R., 2000. Bases and limits to using 'degree day' units. Eur. J. Agron. 13, 1-10.

Brady, N.C., Weil, R.R., 1999. The Nature and Properties of Soils. Prentice-Hall, Inc., Upper Saddle River, NJ.

Breshears, D.D., Myers, O.B., Barnes, F.J., 2009. Horizontal heterogeneity in the frequency of plantavailable water with woodland intercanopy-canopy vegetation patch type rivals that occurring vertically by soil depth. Ecohydrology 2, 503-519.

Breshears, D.D., Myers, O.B., Johnson, S.R., Meyer, C.W., Martens, S.N., 1997a. Differential use of spatially heterogeneous soil moisture by two semiarid woody species: Pinus edulis and Juniperus monosperma. J. Ecol. 85, 289-299.

Breshears, D.D., Rich, P.M., Barnes, F.J., Campbell, K., 1997b. Overstory-imposed heterogeneity in solar radiation and soil moisture in a semiarid woodland. Ecol. Appl. 7, 1201-1215.

Campbell Scientific, Inc., 1983. Model 227 Delmhorst Cylindrical Soil Moisture Block Instruction Manual. Campbell Scientific, Logan, UT.

Chambers, J.C., Meyer, S.E., Whittaker, A., Roundy, B.A., Blank, R.R., 2007. What makes Great Basin sagebrush ecosystems invasible by Bromus tectorum? Ecol. Monogr. 77, 117-145.

Cline, N.L., Kormos, P., Williams, C.J., Roundy, B.A., Pierson, F.B., 2010. Hydrologic response to mechanical shredding in a juniper woodland. Rangeland Ecol. Manage. 63, 467-477. 
D'Antonio, C.M., Chambers, J.C., Loh, R., Tunison, J.T., 2009. Applying ecological concepts to the management of widespread grass invasions. In: Inderjit, R.L., (Ed.). Management of Invasive Weeds. Springer, Dordrecht, Netherlands, pp. 123-149.

Emerson, F.W., 1932. The tension zone between the grama grass and piñon-juniper associations in northeastern New Mexico. Ecology 13, 347-358.

Facelli, J.M., Pickett, S.T., 1991. Plant litter: Its dynamics and effects on plant community structure. Bot. Rev. 57, 1-32.

Gillette, D.A., Pitchford, A.M., 2004. Sand flux in the northern Chihuahuan desert, New Mexico, USA, and the influence of mesquite-dominated landscapes. J. Geophys. Res. Earth. 109. doi:10.1029/2003JF000031.

Hardegree, S.P., Flerchinger, G.N., van Vactor, S.S., 2003. Hydrothermal germination response and the development of probabilistic germination profiles. Ecol. Model. 167, 305-322.

Harris, G.A., 1967. Some competitive relationships between Agropyron spicatum and Bromus tectorum. Ecol. Monogr. 37, 89-111.

Hillel, D., 2004. Introduction to Environmental Soil Physics. Academic Press, San Diego, CA.

Idso, S.B., Jackson, R.D., Reginato, R.J., 1978. Extending the "degree day" concept of plant phenological development to include water stress effects. Ecology 59, 431-433.

Jaeger, W.K., Cross, R., Egelkraut, T.M., 2007. Biofuel potential in Oregon: Background and evaluation of options. Special Report 1078. Oregon State Univer. Ext. Serv., Corvallis, OR.

Johnsen, T.N., 1962. One-seed juniper invasion of northern Arizona grasslands. Ecol. Monogr. 32:187207.

Knapp, A.K., Briggs, J.M., Collins, S.L., Archer, S.R., Bret-Harte, M.S., Ewers, B.E., Peters, D.P., Young, D.R., Shaver, G.R., Pendall, E., Cleary, M.B., 2008. Shrub encroachment in North American grasslands: 
shifts in growth form dominance rapidly alters control of ecosystem carbon inputs. Glob. Change Biol. 14, 615-623.

427 Lebron, I., Madsen, M.D., Chandler, D.G., Robinson, D.A., Wendroth, O., Belnap, J., 2007. Ecohydrological controls on soil moisture and hydraulic conductivity within a pinyon-juniper woodland. Water Resour. Res. 43, 1-15.

430

Leffler, A.J., Ryel, R.J., 2012. Resource pool dynamics: Conditions that regulate species interactions and

Leffler, A.J., Ryel, R.J., Hipps, L., Ivans, S., Caldwell, M.M., 2002. Carbon acquisition and water use in a northern Utah Juniperus osteosperma (Utah juniper) population. Tree Physiol. 22, 1221-1230.

Miller, R.F., Bates, J.D., Svejcar, T.J., Pierson, F.B., Eddleman, L.E., 2005. Biology, Ecology, and

Mclver, J.D., Brunson, M., Bunting, S.C., 2010. The Sagebrush Steppe Treatment Evaluation Project (SageSTEP): A Test of State-and-Transition Theory. Gen. Tech. Rep. RMRS-GTR-237, US For. Serv. Rocky Mountain Res. Stn., Fort Collins, CO. Management of Western Juniper. Tech. Bull. 152, Agric. Exp. Stn., Oregon State Univer., Corvallis, OR.

Miller, R.F., Ratchford, J., Roundy, B.A., Tausch, R.J., Pereia, C., Hulet, A., Chambers, J.C., 2013. Response of conifer encroached shrublands in the Great Basin to prescribed fire and mechanical treatments. Rangeland Ecol. Manage.

Miller, R.F., Rose, J.R., 1999. Fire history and western juniper encroachment in sagebrush steppe. J. Range Manage. 52:550-559.

Miller, R.F., Svejcar, T.J., Rose, J.R., 2000. Impacts of western juniper on plant community composition 447 and structure. J. Range Manage. 53:574-585. 
Miller, R.F., Wigand, P.E., 1994. Holocene changes in semiarid pinyon-juniper woodlands: Responses to climate, fire, and human activities in the U.S. Great Basin. Bioscience 44, 465-474.

Newman, B.D., Gard, M.O., Breshears, D.D., 2010. Evapotranspiration partitioning in a semiarid woodland: Ecohydrologic heterogeneity and connectivity of vegetation patches. Vadose Zone J. 9, 561-572.

[PIC] Pinchot Institute for Conservation., 2002. An introduction to the national fire plan: history, structure, and relevance to communities. Available at http://www.pinchot.org. Accessed Jun. 2013.

PRISM Climate Group, 2008. Parameter-elevation regression on independent slopes model. Available at http://prism.oregonstate.edu. Accessed Feb. 2008.

Rau, B.M., Johnson, D.W., Blank, R.R., Tausch, R.J., Roundy, B.A., Miller, R.F., Caldwell, T.G., Lucchesi, A., 2011. Woodland expansion's influence on belowground carbon and nitrogen in the Great Basin U.S. J. Arid Environ. 75, 827-835.

Rawlins, J.K., Roundy, B.A., Egget, D., Cline, N., 2012. Predicting germination in semi-arid wildland seedbeds II. Field validation of wet thermal-time models. Environ. Exp. Bot. 76, 68-73.

Robinson, D.A., Lebron, I., Ryel, R.J., Jones, S.B., 2010. Soil water repellency: A method of soil moisture sequestration in pinyon-juniper woodland. Soil Sci. Soc. Am. J. 74, 624-634.

Roundy, B.A., Miller, R.F., Tausch, R.J., Young, K.R., Hulet, A., Rau, B., Jessop, B., Chambers, J.C., Eggett, D., 2013a. Understory cover responses to piñon-juniper treatments across tree cover gradients in the Great Basin. Rangeland Ecol. Manage.

Roundy, B.A., Whittaker, A., Chambers, J.C., Hardegree, S.P., 2007. Prediction of cheatgrass field germination potential using wet thermal accumulation. Rangeland Ecol. Manage. 60, 613-623. 
Roundy, B.A., Young, K.R., Cline, N., Hulet, A., Miller, R.F., Tausch, R.J., Chambers, J.C., Rau, B., 2013b. Piñon-juniper reduction effects on soil temperature and water availability of the resource growth pool. Rangeland Ecol. Manage.

Ryel, R.J., Leffler, A.J., Ivans, C., Peek, M.S., Caldwell, M.M., 2010. Functional differences in water-use patterns of contrasting life forms in Great Basin Steppelands. Vadose Zone J. 9, 1-13.

[SageSTEP] Sagebrush Steppe Treatment Evaluation Project., 2011. Guide to vegetation treatment costs for land management in the Great Basin. URL: http://www.sagestep.org. Accessed: 25 Jun 2013.

Schlesinger, W.H., Reynolds, J.F., Cunningham, G.L., Huenneke, L.F., Jarrell, W.M., Virginia, R.A., Whitford, W.G., 1990. Biological feedbacks in global desertification. Science. 247, 1043-1048.

Skog, K.E., Rummer, R., Jenkins, B., Parker, N., Tittmann, P., Hart, Q., Nelson, R., Gray, E., Schmidt, A., Patton-Mallory, M., Gordon, G., 2009. A strategic assessment of biofuels development in the western states. In: McWilliams, W., Moisen, G., Czaplewski, R., (Eds.). In: Forest Inventory and Analysis (FIA) Symposium 2008. RMRS-P-56CD. US For. Serv. Rocky Mountain Res. Stn., Fort Collins, CO.

Wainwright, J., Parsons, A.J., Abrahams, A.D., 2000. Plot-scale studies of vegetation, overland flow and erosion interactions: case studies from Arizona and New Mexico. Hydrol. Process. 14, 29212943.

Wang, J.Y., 1960. A critique of the heat unit approach to plant response studies. Ecology 41, 785-790.

West, N.E., 1984. Successional patterns and productivity of pinyon-juniper ecosystems. p. 1301-1332. In: Committee on Developing Strategies for Rangeland Management (Ed.). Developing Strategies for Range Management. Westview Press, Boulder, CO.

Young, K.R., 2012. Plant establishment and soil microenvironments in Utah juniper masticated woodlands. [dissertation]. Brigham Young Univer., Provo, UT. 
493 Young, J.A., Easi, D.A., Evans, R.A., 1984. Stem flow on western juniper (Juniperus occidentalis) trees. Weed Sci. 32, 320-327.

495 Young, K.R., Roundy, B.A., Eggett, D.L., 2013. Plant establishment in masticated Utah juniper woodlands.

496 Rangeland Ecol. Manage. 66. 
497 Figure 1. Untreated control area identifying microsite types.

498 


\section{管

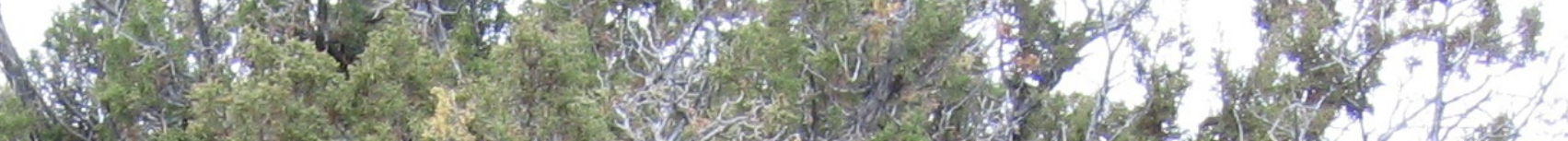

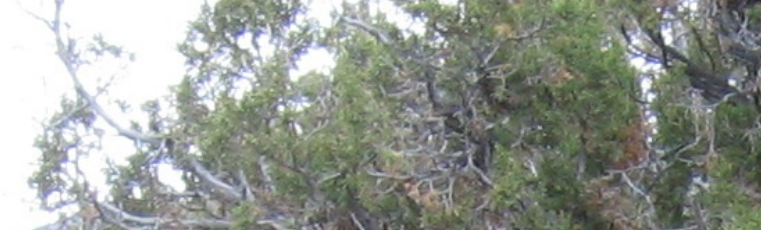 \\ a. $y^{2}+2$

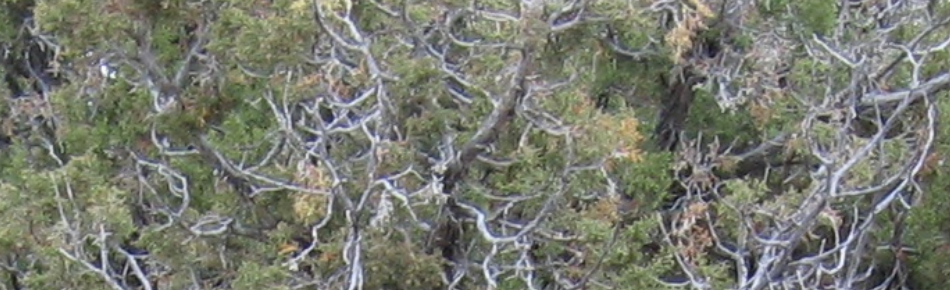

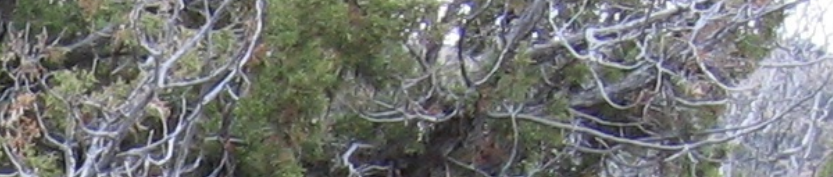

(x)

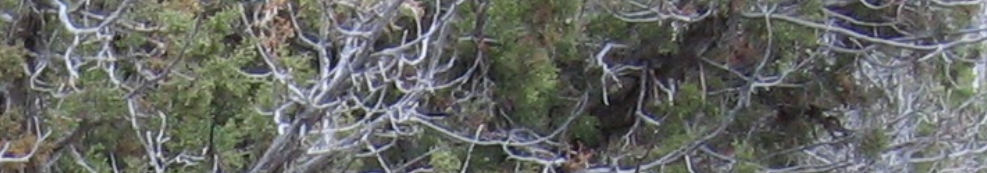

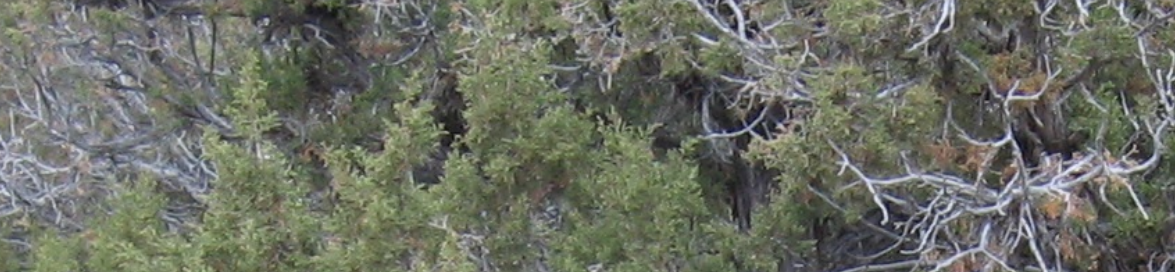
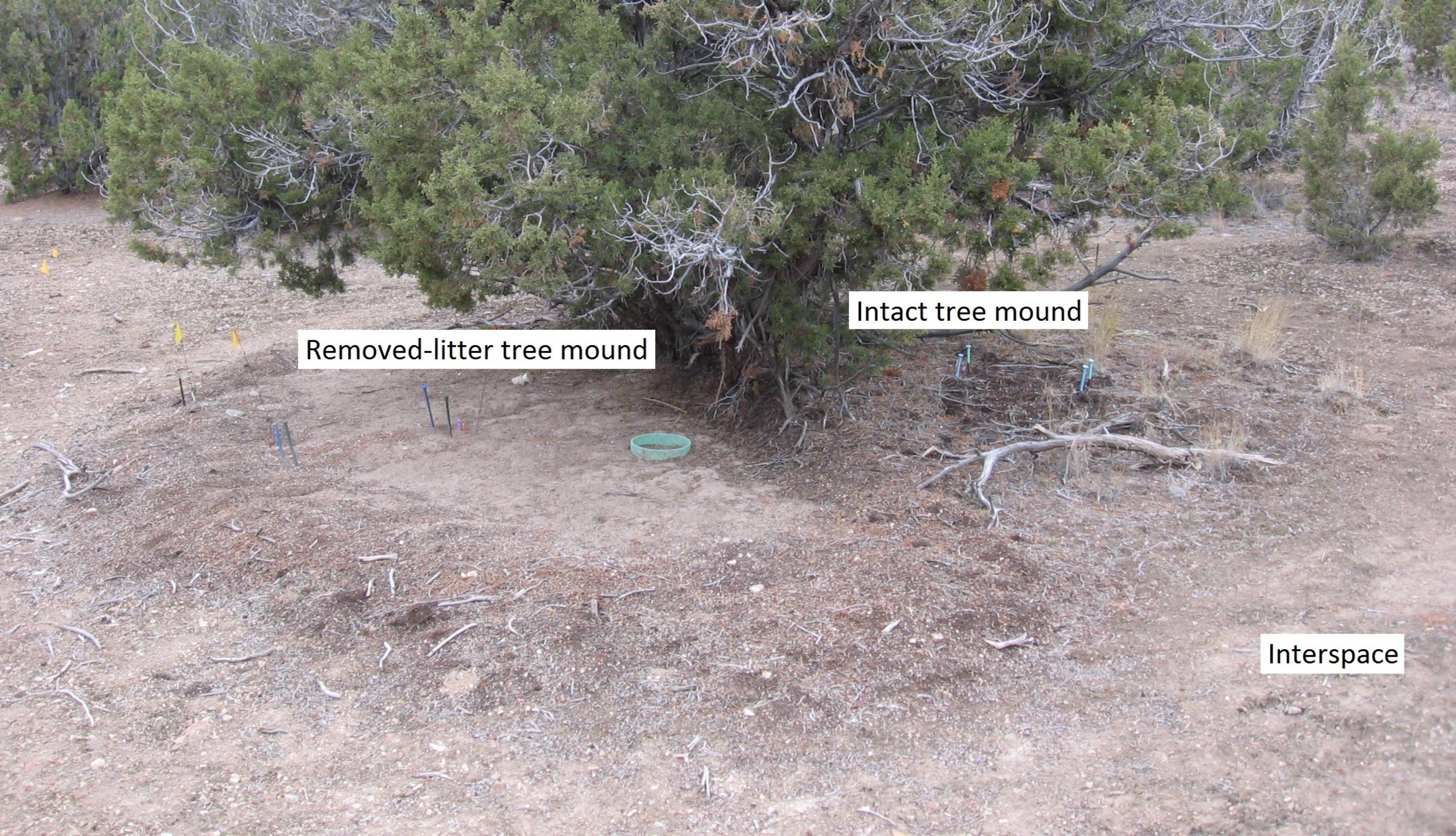
499 Figure 2. Masticated area identifying microsite types.

500 


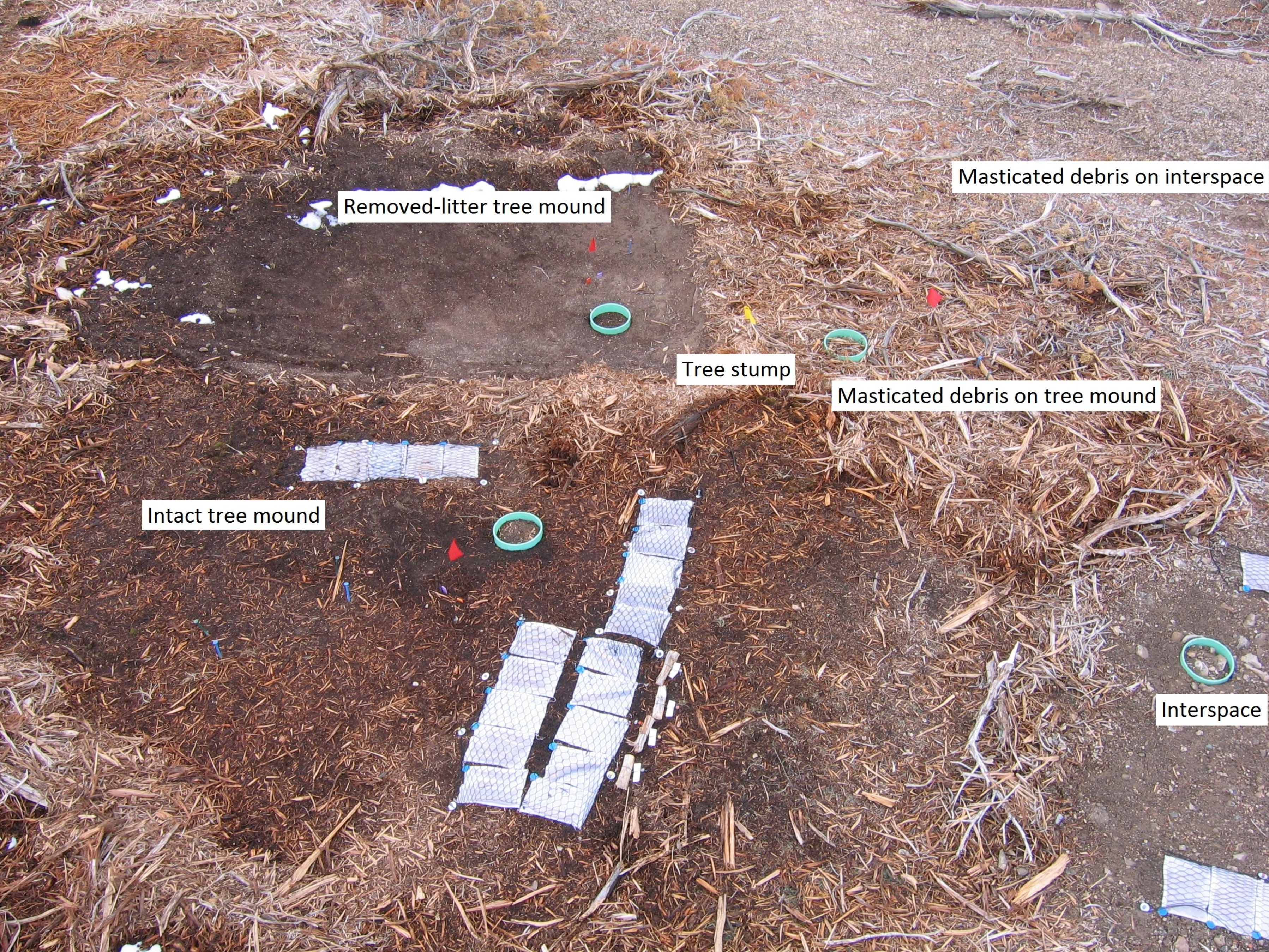


501 Figure 3. Wet day comparisons between untreated and masticated areas. For intact juniper tree

502 mounds, masticated was greater than untreated during fall, winter, and spring $(P<0.001)$. For

503 interspaces, masticated was greater than untreated for the lower two soil depths during spring and the

504 lowest soil depth during other seasons. Note: different scales for different seasons.

505 


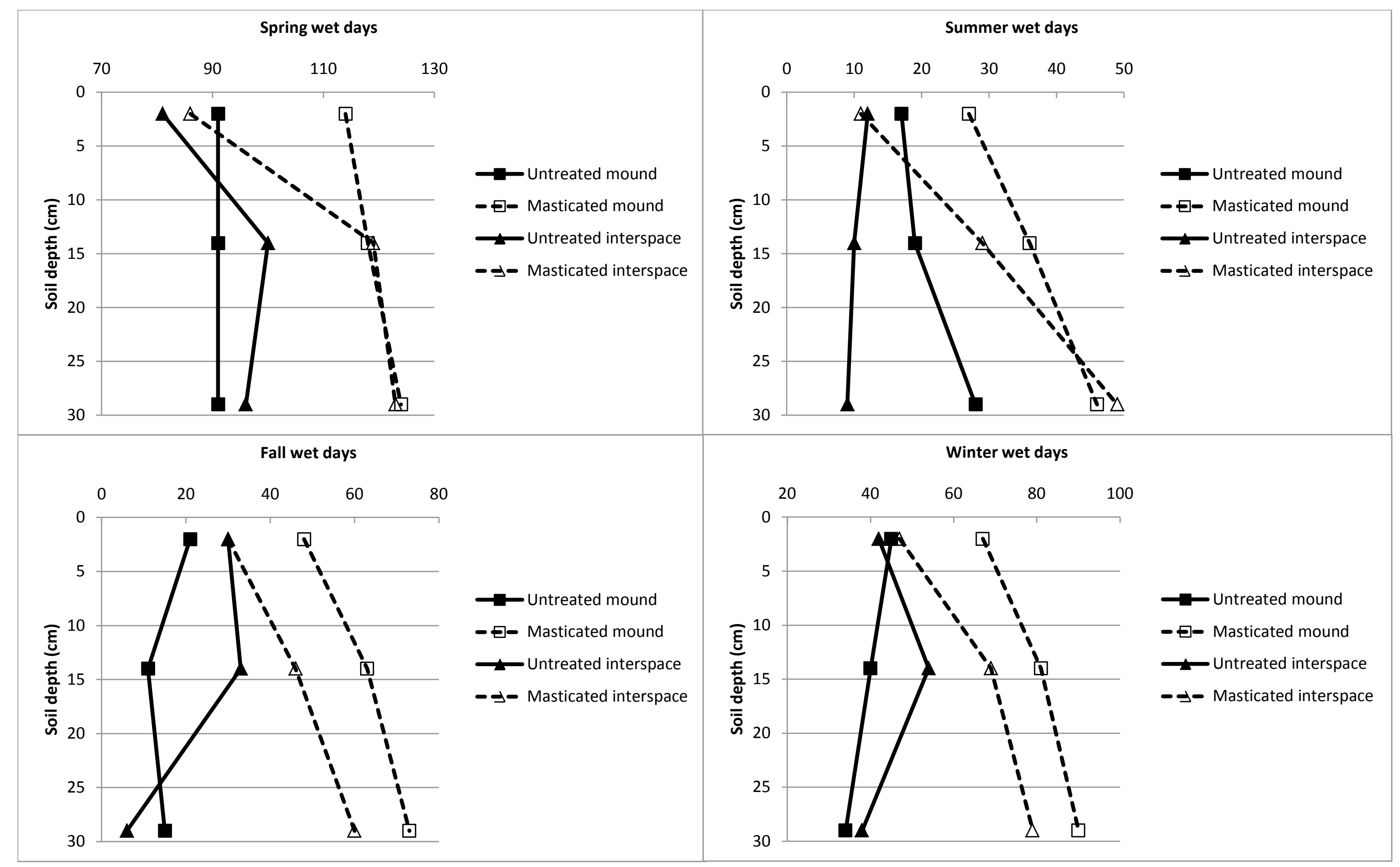

Figure 3. 
506 Figure 4. Wet degree day comparisons between untreated and masticated areas. For intact juniper tree 507 mounds, masticated was greater than untreated during all seasons except winter $(P<0.001)$. For 508 interspaces, masticated was greater than untreated for the lower two soil depths during spring and 509 summer and for the lowest soil depth in fall $(P<0.001)$. Note: different scales for different seasons. 


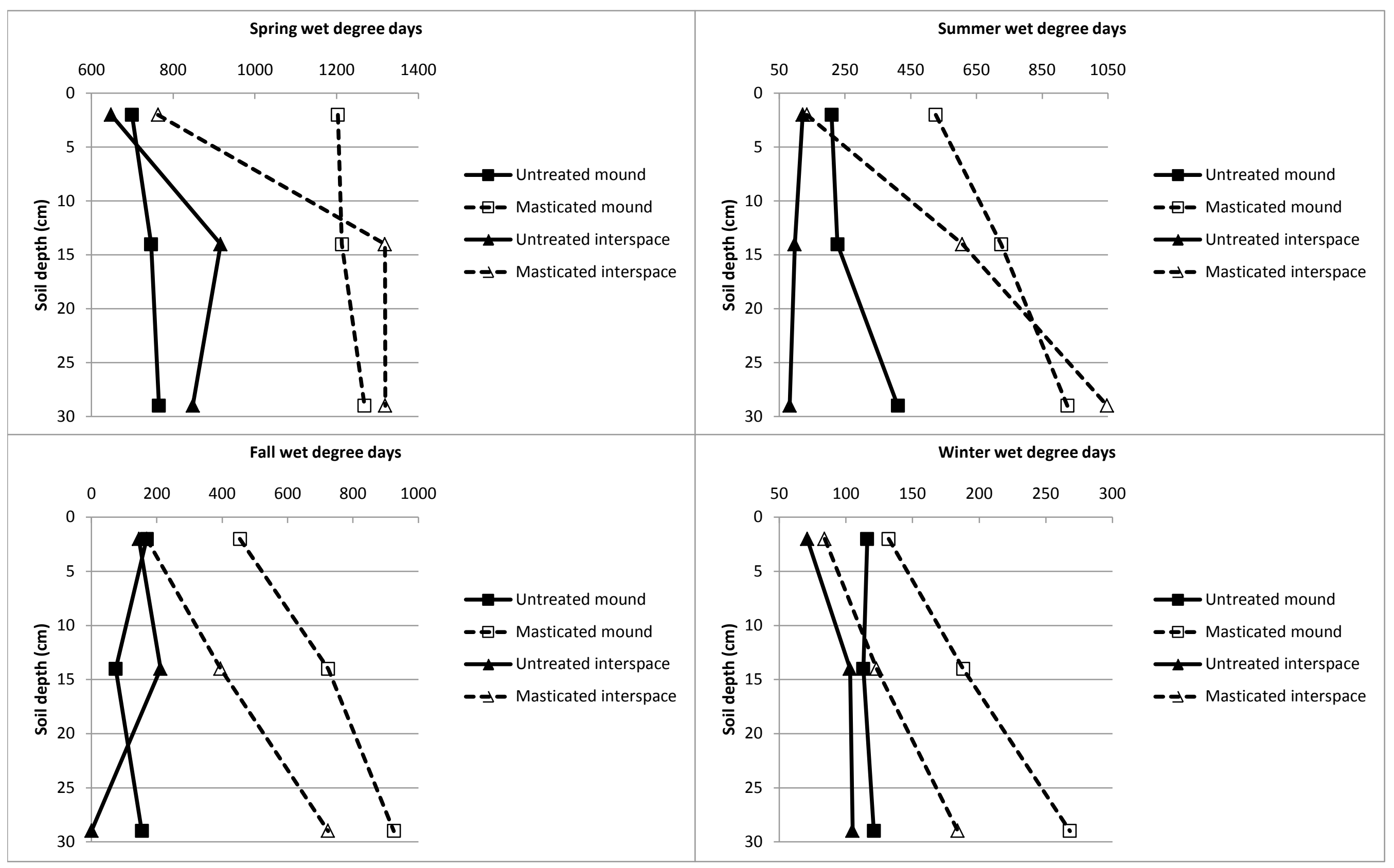

Figure 4. 
510 Table 1. Mixed-model analysis of variance and Type III F-tests from maximum likelihood estimation for

511 the response variables of wet, degree, and wet degree days. We assigned each treatment (trt) by

512 microsite combination as one of eight levels of the combined main effect of trt-microsite. Denominator

513 degrees of freedom $(\mathrm{df})=3204$.

\begin{tabular}{lcccc}
\hline & & \multicolumn{3}{c}{ P-value } \\
\cline { 3 - 5 } Effect & Numerator df & Wet days & Degree days & Wet degree days \\
\hline Trt-microsite (T-M) & 7 & $<0.001$ & $<0.001$ & $<0.001$ \\
Depth (D) & 2 & $<0.001$ & $<0.001$ & $<0.001$ \\
Season (S) & 5 & $<0.001$ & $<0.001$ & $<0.001$ \\
T-M*D & 14 & $<0.001$ & 0.25 & $<0.001$ \\
T-M*S & 35 & $<0.001$ & $<0.001$ & $<0.001$ \\
D*S & 10 & $<0.001$ & $<0.001$ & $<0.001$ \\
T-M*D*S & 70 & $<0.001$ & $<0.001$ & $<0.001$ \\
\hline
\end{tabular}

514 
515 Table 2. Overall treatment comparisons between masticated and untreated areas across microsite

516 types, soil depths, and seasons using maximum-likelihood estimates (degrees of freedom $=3204$ ).

\begin{tabular}{lccccr}
\hline Response & SE & t-value & Masticated & Untreated & p-value \\
\hline Wet Days & 1.58 & 17.3 & 70 & 42 & $<0.001$ \\
Degree Days & 11.93 & 2.68 & 1009 & 977 & 0.007 \\
Wet Degree Days & 18.70 & 16.61 & 627 & 316 & $<0.001$ \\
\hline
\end{tabular}


519 not significantly different $(P<0.001)$.

\begin{tabular}{|c|c|c|c|c|c|c|c|c|c|}
\hline \multirow[b]{2}{*}{ Mastication effects } & \multirow[b]{2}{*}{$\begin{array}{l}\text { Depth } \\
(\mathrm{cm})\end{array}$} & \multicolumn{2}{|c|}{ Spring } & \multicolumn{2}{|c|}{ Summer } & \multicolumn{2}{|c|}{ Fall } & \multicolumn{2}{|c|}{ Winter } \\
\hline & & Untreated & Masticated & Untreated & Masticated & Untreated & Masticated & Untreated & Masticated \\
\hline \multirow[t]{3}{*}{ Intact tree mound } & $1-3$ & $1118 b$ & $1427 a$ & $1306 b$ & $1557 a$ & $1068 a$ & $1132 a$ & $96 a$ & $83 a$ \\
\hline & $13-15$ & $1090 b$ & $1354 a$ & $1259 b$ & $1463 a$ & $1125 a$ & $1191 a$ & $140 a$ & $137 a$ \\
\hline & $28-30$ & $1085 b$ & $1274 a$ & $1237 b$ & $1387 a$ & $1197 a$ & $1255 a$ & $231 a$ & $221 a$ \\
\hline \multirow[t]{3}{*}{ Interspace } & $1-3$ & $1509 a$ & $1505 a$ & $1678 a$ & $1645 a$ & $947 b$ & $1045 a$ & $27 a$ & $50 a$ \\
\hline & $13-15$ & $1440 a$ & $1447 a$ & $1562 a$ & $1551 a$ & $1014 b$ & $1132 a$ & $61 a$ & $84 a$ \\
\hline & $28-30$ & $1370 a$ & $1356 a$ & $1494 a$ & $1481 a$ & $1119 b$ & $1219 a$ & $144 a$ & $161 a$ \\
\hline Tree mound effects & & Intact & Removed & Intact & Removed & Intact & Removed & Intact & Removed \\
\hline \multirow[t]{3}{*}{ Untreated } & $1-3$ & $1118 b$ & $1355 a$ & $1306 b$ & $1516 a$ & $1068 a$ & 1099a & $96 a$ & $80 a$ \\
\hline & $13-15$ & $1090 b$ & $1250 a$ & $1259 b$ & $1385 a$ & $1125 a$ & $1158 a$ & $140 a$ & $103 a$ \\
\hline & $28-30$ & $1085 b$ & $1202 a$ & $1237 a$ & $1316 a$ & $1197 a$ & $1225 a$ & $231 a$ & $183 a$ \\
\hline \multirow[t]{3}{*}{ Masticated } & $1-3$ & $1427 b$ & $1529 a$ & $1557 b$ & $1676 a$ & $1132 a$ & $1071 a$ & $83 a$ & $46 a$ \\
\hline & $13-15$ & $1354 a$ & $1410 a$ & $1463 a$ & $1522 a$ & $1191 a$ & $1124 a$ & $137 a$ & $80 a$ \\
\hline & $28-30$ & $1274 a$ & $1329 a$ & $1387 a$ & $1443 a$ & $1255 a$ & $1208 a$ & $221 a$ & $173 a$ \\
\hline $\begin{array}{l}\text { Masticated debris } \\
\text { effects }\end{array}$ & & Debris & No debris & Debris & No debris & Debris & No debris & Debris & No debris \\
\hline \multirow[t]{3}{*}{ Intact tree mound } & $1-3$ & $1165 b$ & $1427 a$ & $1327 b$ & $1557 a$ & $1098 a$ & $1132 a$ & $125 a$ & $83 a$ \\
\hline & $13-15$ & $1139 b$ & $1354 a$ & $1295 b$ & $1463 a$ & $1157 a$ & $1191 a$ & $170 a$ & $137 a$ \\
\hline & $28-30$ & $1088 b$ & $1274 a$ & $1246 b$ & $1387 a$ & $1223 a$ & $1255 a$ & $241 a$ & $221 a$ \\
\hline \multirow[t]{3}{*}{ Interspace } & $1-3$ & $1240 b$ & $1505 a$ & $1434 b$ & $1645 a$ & $1051 a$ & $1045 a$ & $87 a$ & $50 a$ \\
\hline & $13-15$ & $1201 b$ & $1447 a$ & $1376 b$ & $1551 a$ & $1125 a$ & $1132 a$ & $146 a$ & $84 a$ \\
\hline & $28-30$ & $1139 b$ & $1356 a$ & $1314 b$ & $1481 a$ & $1192 a$ & $1219 a$ & $214 a$ & $161 a$ \\
\hline
\end{tabular}


521 Table 4. Soil cover type effects on wet and wet degree days. Estimates in paired columns at the same soil depth with the same letters are not

522 significantly different $(P<0.001)$.

\begin{tabular}{|c|c|c|c|c|c|c|c|c|c|}
\hline \multirow[b]{2}{*}{$\begin{array}{l}\text { Wet days } \\
\text { Tree mound effects }\end{array}$} & \multirow[b]{2}{*}{ Depth $(\mathrm{cm})$} & \multicolumn{2}{|c|}{ Spring } & \multicolumn{2}{|c|}{ Summer } & \multicolumn{2}{|c|}{ Fall } & \multicolumn{2}{|c|}{ Winter } \\
\hline & & Intact & Removed & Intact & Removed & Intact & Removed & Intact & Removed \\
\hline \multirow[t]{3}{*}{ Untreated } & $1-3$ & $91 a$ & $67 b$ & $17 a$ & $15 a$ & $21 a$ & $23 a$ & $45 a$ & $52 a$ \\
\hline & $13-15$ & $91 a$ & $101 a$ & 19a & $24 a$ & $11 a$ & $17 a$ & $40 a$ & $44 a$ \\
\hline & $28-30$ & $91 a$ & $98 a$ & $28 a$ & $37 a$ & $15 a$ & $4 a$ & $34 a$ & $30 a$ \\
\hline \multirow[t]{3}{*}{ Masticated } & $1-3$ & $114 a$ & $86 b$ & $27 a$ & $14 a$ & $48 a$ & $38 a$ & $67 a$ & $56 a$ \\
\hline & $13-15$ & $118 a$ & $122 a$ & $36 a$ & $29 a$ & $63 a$ & $56 a$ & $81 a$ & $78 a$ \\
\hline & $28-30$ & $124 a$ & $126 a$ & $46 a$ & $49 a$ & $73 a$ & $67 a$ & $90 a$ & $90 a$ \\
\hline Masticated debris effects & & Debris & No debris & Debris & No debris & Debris & No debris & Debris & No debris \\
\hline \multirow[t]{3}{*}{ Intact tree mound } & $1-3$ & $121 a$ & $114 a$ & $28 a$ & $27 a$ & $45 a$ & $48 a$ & $76 a$ & $67 a$ \\
\hline & $13-15$ & $122 a$ & $118 a$ & $33 a$ & $36 a$ & $51 a$ & $63 a$ & $82 a$ & $81 a$ \\
\hline & $28-30$ & $125 a$ & $124 a$ & $38 a$ & $46 a$ & $63 a$ & $73 a$ & $91 a$ & $90 a$ \\
\hline \multirow[t]{3}{*}{ Interspace } & $1-3$ & $117 a$ & $86 b$ & $18 a$ & $11 a$ & $43 a$ & $30 a$ & $71 a$ & $47 \mathrm{~b}$ \\
\hline & $13-15$ & $126 a$ & $119 a$ & $36 a$ & $29 a$ & $51 a$ & $46 a$ & $80 a$ & $69 a$ \\
\hline & $28-30$ & $128 a$ & $123 a$ & $42 a$ & $49 a$ & $59 a$ & $60 a$ & $82 a$ & 79a \\
\hline \multicolumn{10}{|l|}{ Wet degree days } \\
\hline Tree mound effects & & Intact & Removed & Intact & Removed & Intact & Removed & Intact & Removed \\
\hline \multirow[t]{3}{*}{ Untreated } & $1-3$ & $699 a$ & $527 a$ & $209 a$ & $178 a$ & $169 a$ & $143 a$ & $116 a$ & $131 a$ \\
\hline & $13-15$ & $746 a$ & $924 a$ & $227 a$ & $356 a$ & $74 a$ & $162 a$ & $113 a$ & $107 a$ \\
\hline & $28-30$ & $765 a$ & $945 a$ & $411 a$ & $657 a$ & $154 a$ & $16 a$ & $121 a$ & $85 a$ \\
\hline \multirow[t]{3}{*}{ Masticated } & $1-3$ & $1203 a$ & $809 b$ & $526 a$ & $198 b$ & $454 a$ & $241 a$ & $132 a$ & $97 a$ \\
\hline & $13-15$ & $1213 a$ & $1346 a$ & $725 a$ & $596 a$ & $724 a$ & $563 a$ & $188 a$ & $130 a$ \\
\hline & $28-30$ & $1268 a$ & $1357 a$ & $927 a$ & 1035a & $925 a$ & $827 a$ & $268 a$ & 209a \\
\hline
\end{tabular}




\begin{tabular}{lccccccccc} 
Masticated debris effects & & Debris & No debris & Debris & No debris & Debris & No debris & Debris & No debris \\
\hline Intact tree mound & $1-3$ & $1091 a$ & $1203 a$ & $478 a$ & $526 a$ & $401 a$ & $454 a$ & $171 a$ & $132 a$ \\
& $13-15$ & $1092 a$ & $1213 a$ & $581 a$ & $725 a$ & $573 a$ & $724 a$ & $209 a$ & $188 a$ \\
& $28-30$ & $1097 a$ & $1268 a$ & $674 a$ & $927 a$ & $782 a$ & $925 a$ & $285 a$ & $268 a$ \\
& & & & & & & & & \\
& $1-3$ & $1103 a$ & $763 b$ & $284 a$ & $134 a$ & $282 a$ & $169 a$ & $146 a$ & $84 a$ \\
Interspace & $13-15$ & $1215 a$ & $1318 a$ & $676 a$ & $607 a$ & $499 a$ & $395 a$ & $197 a$ & $123 a$ \\
& $28-30$ & $1198 a$ & $1319 a$ & $781 b$ & $1048 a$ & $709 a$ & $724 a$ & $250 a$ & $184 a$ \\
\hline
\end{tabular}

